心拍 R-R 間隔を用いた簡便な作業負担評価法の試み

\author{
○高橋雄三、神代雅晴、飯田憲一・、近藤雄二“* \\ 産業医科大学 産業生態科学研究所 人間工学研究室 \\ $*$; 北海道工業試験場 \\ **; 天理大学 健康管理学
}

\title{
Trial of Work Load Evaluation System using Heart Beat R-R Intervals
}

Yuzo TAKAHASHI, Masaharu KUMASHIRO, Kenichi IIDA* , and Yuji KONDO*

Department of Ergonomics, University of Occuaptional and Environmental Health, JAPAN * ; Hokkaido Industrial Research Institute, JAPAN

** ; Tenri University, JAPAN

\section{1.はじめに}

現場で简便に作業負担を評価する指標 の一つとして心拍数の変化を用いること が多い。しかし心拍数は基準となる個人 差の影響が大きいことや心拍数の上昇や 下降だけでは短期的な作業の変化をとら えにくいという側面がある。従って作業 負担の相対的な評価に心拍数を用いる際、 考慮すべき点は多い。

本研究では現場対応型の作業負担評価 法の試みとして重筋作業、選別作業など に従事している作業者の心拍 R-R 間隔を 測定し、R-R 間隔の変動を示す指標の作 業毎の作業負担の相対的な比較への適用 可能性について検討した。

\section{2. 方法}

業態の異なる 2 つの工場でおこなわれ ている 7 種の作業に従事している作業者 の心拍 R-R 間隔のデータを対象とした。

\section{1.被䀦者}

作業に従事する上で特に障害となる心 炡血管系の疾患を持たない作業者 12 人

(内訳 ; 男性 5 人 : $43 \sim 59$ 歳、女性 7 人 $43 \sim 56$ 歳)。

\section{2.心拍数の湘定}

(1)装直：64K バイト心拍メモリ装㯰（竹 井機器工業株式会社, T.K.K.6001)、ハート レートアナライザーII（竹井機器工業株 式会社 T.K.K.6001)

(2)測定方法

電極を CM5 位置に貼付し心拍 R-R 間隔 を計測

\section{3.作業䘽察}

7 種の作業の内 5 種の作業については $\mathrm{R}-\mathrm{R}$ 間隔の測定と同時に 30 秒間隔のワー クサンプリングをおこなった。また残り
のデータについては事前におこなった口 ークサンプリングのデータから、分析対 象時間帯に従事していた作業を推定した。 作業内容と R-R 間隔との同期誤差は土1 分以下になるように測定した。

\section{4. 解析対象}

全ての作業観察データを検討した結果、 本研究で解析の対象としたデー夕は各作 業者とも主作業が定常状態にあると判断 された 10:30〜 11:30の 1 時間とした。内 訳は工場 $\mathrm{A}$ では 6 作業 9 人、工場 $\mathrm{B}$ では 3 作業 3 人 $\times 3$ 日分（延べ 9 人）。

\section{5.解析方法}

(1)データの補正：測定装㯰の精度（1/100 秒）ならびに体動や汗の影響を考虑して、 得られたデータに移動平均処理を施した。 (2)変動を示す指標 : 本研究では心拍数は 個人差と負担の両方を含んだ指標と定義 した。一方、個人差を最小にし負担要素 による R-R 間隔の変動を見るために単位 時間当たりの R-R 間隔の平均值とその標 準偏差を算出した。

(3)検討した指標：(2)より、計算が簡便で、 また変動を定量化する指標として下記の 6 種の指標について検討した。尚、心拍 数との比較検討のため解析の単位時間を 1 分とした。各指標について表 1 に示す。

表 1 検討した指標

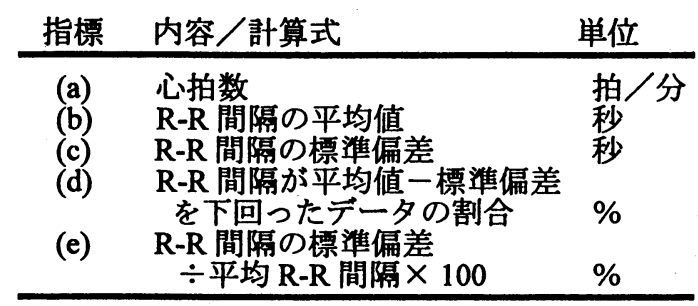




\section{3. 結果}

\section{1. 作羓毎の各指標の平均值}

同一作業に従事する作業者の述べ人数 が 2 人以上となる 6 種の作業について検 討した。表 2 には作業毎の各指標の平均 值を示す。R-R 間隔と比較して心拍数を 基準としたデータの方がより作業間の差 異が大きく現れた。

\section{2. 指標相互の関保}

指標 (a)から指標(e)の間の Pearsonの相関 係数を算出した。結果、指標 (a)は残り全 ての指標との間に $\mathrm{p}<0.05$ の有意の相関が 認められた。しかし指標(b)以外の $\mathrm{r}^{2}$ はい ずれも 0.001 以下であった。従って HR と $\mathrm{R}-\mathrm{R}$ 間隔の標準偏差を基隻とした指標と の間の連動は小さいものと考えられる。

\subsection{R-R 間隔の標準偏差を用いた指標の}

\section{有用性}

指標(c)から指標(d)の内、作業負担の简 便な指標として有用な指標を検討するた めに、被験者をプールして「各作業 $\times$ 各 指標」の一元配置分散分析をおこない、 更に scheffe 法による多重比較をおこなっ た。結果、いずれの指標においても作業 間に $\mathrm{p}<0.001$ で有意差が認められた（指標 (c) ; F=71.182、指標 (d) ; F=8.497、指標 (e)

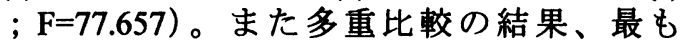
良く作業を分離できた指標は指標(e)であ った。各作業間の多重比較の結果を図 1 に示す。図 1 より各作業は 3 つの群、す なわち群 1 (作業 $\mathrm{E}$ と作業 $\mathrm{B}$ )、群 2 (作業 $\mathrm{F}$ と作業 $\mathrm{A}$ )、群 3 (作業 D と作業 C) に わかれた。各群内では作業間に有意差は 認められなかったものの、群間で比較す ると $\mathrm{p}<0.001$ の有意差が認められ、6つの 作業は指標(e)の值を用いることによって

「群 $1>$ 群 $2>$ 群 3 」の関係が得られた。

\section{4.指標(fを用いた作羓ごとの特徽}

作業観察のデータから各群ごとの特徽 について検討した結果を表 3 にまとめた。

\section{4 .まとめ}

今回、検討した指標の内、心拍数と比 較して作業の特徴がより反映された指標 は(e)であった。また指標(e)をもとに $3 つ$ の群を構成することができた。

本研究では日内の作業の内、定常状態 にあるとされた 1 時間のデータについて 分析しいること、対象とする作業が少な いことから、妥当性の検討には至らなか った。また作業環境の差異、性差につい ては検討していない。

今後は指標の妥当性の検討と併せて更 に調査する作業数を増やすと共に、短期 的な作業の変化による指標の変化を検出 するために、作業の解析レベルをあげる 必要がある。

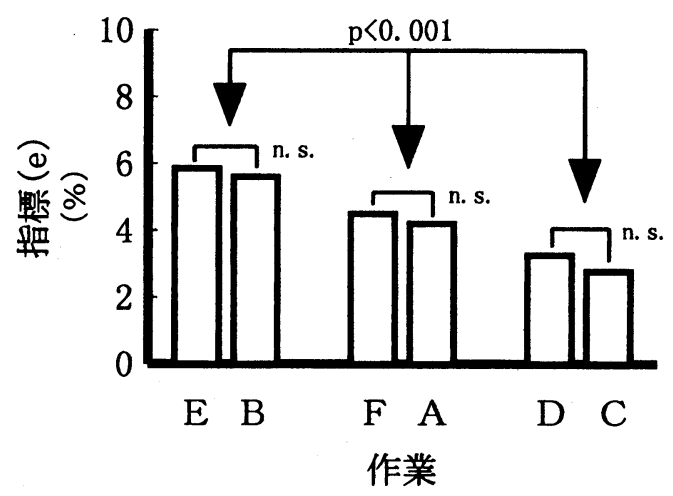

図 1 指標 $(\mathrm{e})$ を用いた工程間の比較

\begin{tabular}{|c|c|c|c|}
\hline 群 & 作業 & $\begin{array}{r}\text { 表 } 3 \\
\text { 主な作業 }\end{array}$ & $\begin{array}{l}\text { 徵 } \\
\text { 作業の特徴 }\end{array}$ \\
\hline 群 1 & $\begin{array}{l}\mathrm{E} \\
\mathrm{B}\end{array}$ & $\begin{array}{l}\text { 引張り、運投、選別 } \\
\text { 運搬、手作業 }\end{array}$ & 全身運動を伴う \\
\hline 群 2 & $\begin{array}{l}\mathrm{F} \\
\mathrm{A}\end{array}$ & $\begin{array}{c}\text { 重量物の運搬 } \\
\text { " }\end{array}$ & $\begin{array}{l}\text { 重量物の運搬を } \\
\text { 伴 }\end{array}$ \\
\hline 群 3 & $\stackrel{\mathrm{D}}{\mathrm{C}}$ & $\begin{array}{l}\text { 目視選別 } \\
\text { 手作羓 }\end{array}$ & $\begin{array}{l}\text { 瘁勢拘束を伴う } \\
\text { 作密 }\end{array}$ \\
\hline
\end{tabular}

表 2 工程毎の各指標の平均値

\begin{tabular}{|c|c|c|c|c|c|c|}
\hline 作業 & データ数 & 指標(a) & 指標(b) & 指標(c) & 指標(d) & 指標(e) \\
\hline A & 180 & 86.97 拍/分 & 0.69 秒 & 0.03 秒 & $17.44 \%$ & $4.20 \%$ \\
\hline B & 120 & 87.60 & 0.68 & 0.04 & 14.41 & 5.61 \\
\hline $\mathrm{C}$ & 180 & 82.70 & 0.74 & 0.02 & 17.47 & 2.76 \\
\hline $\mathrm{D}$ & 119 & 90.45 & 0.66 & 0.02 & 16.98 & 3.24 \\
\hline $\mathrm{E}$ & 229 & 86.56 & 0.69 & 0.04 & 15.31 & 5.85 \\
\hline$F$ & 180 & 96.66 & 0.62 & 0.03 & 15.66 & 4.51 \\
\hline
\end{tabular}

